\title{
USING A CONTEXTUAL METHODOLOGY TO ACCOMMODATE EQUALITY PROTECTIONS ALONG WITH THE OTHER OBJECTIVES OF GOVERNMENT (WITH PARTICULAR REFERENCE TO THE INCOME TAX ACT): "NOT THE RIGHT ANSWER, STUPID. THE BEST ANSWER"1
}

\section{J.E. (TED) FULCHER *}

The article examines the judicial development of the Charter's equality provision. The author proposes a "middle-of-the-road" or contextual approach as the most preferable path for this development. He canvasses the approaches to either side of the "middle ground," those of the democrats and the civil libertarians. He argues that both of these more extreme positions should be discouraged in favour of the more "equivocal" contextual approach.

After explaining how the contextual approach has arisen and been developed in recent Supreme Court cases, the author examines this methodology with respect to the interpretation of the Income Tax Act. He then utilizes the methodology to resolve some difficult factual situations arising from application of the Income Tax Act.
Le présent article examine l'évolution, en justice, de la disposition de la Charte en matière d'égalité. Pour l'auteur, une approche contextuelle tempérée constitue la voie préférable. Il examine les approches situées aux deux extrêmes de ce uchamp intermédiairen, celle des démocrates et celle des défenseurs des libertés civiles. II soutient que ces deux positions extrêmes devraient être découragées en faveur d'une approche plus "équivoque», sensible au contexte.

Après avoir présenté l'historique de cette approche à travers des causes récentes de la Cour supréme, l'auteur l'examine par rapport $a$ l'interprétation de la Loi de l'impót sur le revenu et l'utilise pour résoudre certaines situations factuelles complexes dans ce domaine.

\section{TABLE OF CONTENTS}

I. INTRODUCTION .................. 417

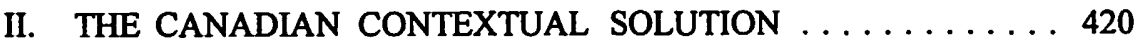

A. ANDREWS v. LAW SOCIETY OF BRITISH COLUMBIA .................. 420

B. EQUALITY PROTECTION IN BRITISH NORTH

AMERICA: A LONG PRAGMATIC HISTORY

C. INTERPRETING THE CHARTER AND THE

INCOME TAX ACT, THE SUPREME COURT'S

METHODOLOGY OF CHOICE: PURPOSE,

EFFECT AND CONTEXT $\ldots \ldots \ldots \ldots \ldots \ldots \ldots \ldots$

Tax Counsel, Edmonton Regional Office, Federal Department of Justice. The opinions expressed are those of the author and not the Department of Justice. The opinions are as of January 1, 1996. A companion article, J.E. Fulcher, "The Income Tax Act, the Rules of Interpretation and Tax Avoidance. Purpose vs. Plain Meaning: Which, When and Why?" appears in (1995) 74 Can. Bar. Rev. 563. The text of the companion article is available free of charge by proceeding to the author's home page on the Internet campus of Canadian Talkback at: http://cantalkback.com.

1 This article is serviced by Canadian Talkback. To either post your own assessment of the article or read the comments of others (including the pre-publication comments of Michael Curley and Eugene Meehan) proceed to the home page of the author on the Internet campus of Canadian Talkback at: http://cantalkback.com. Use of this service is furnished by Mr. Fulcher and is free of charge to the user. Mr. Fulcher may also be reached at ted.fulcher@justice.x400.gc.ca. 


\section{APPLYING CONSTITUTIONAL EQUALITY PROTECTION}

TO THE INCOME TAX ACT . . . . . . . . . . . . . 429

A. BENEFITTING FROM THE AMERICAN

EXPERIENCE: TRIBAL SENSITIVITY . . . . . . . . . . 429

B. THE PURPOSIVE AND CONTEXTUAL APPROACH

MAKES NEW DEMANDS ON OUR JUDICIARY:

THE JUDGE AS DECATHLETE . . . . . . . . . . 430

C. SOME CONTEXTUAL FACTORS THAT ASSIST

IN APPLYING CONSTITUTIONAL EQUALITY

PROTECTION TO THE INCOME TAX ACT . . . . . . 432

D. CONFIRMING THE OBVIOUS: FOR THE DIFFICULT

CASE, THE CONTEXTUAL ANALYSIS HAS TO BE

DONE IN SECTION 15 , NOT SECTION $1 \ldots \ldots \ldots \ldots 444$

E. TESTING THE MISSION STATEMENT:

APPLYING THE CONTEXTUAL METHODOLOGY

TO THE PROBLEMS RAISED IN THE INTRODUCTION . 445

IV. CONCLUSION $\ldots \ldots \ldots \ldots \ldots \ldots \ldots \ldots \ldots \ldots \ldots \ldots \ldots \ldots \ldots$

\section{INTRODUCTION}

With the Thibaudeau trilogy, ${ }^{2}$ the Supreme Court of Canada has provided further evidence that Canada is in the process of fashioning an effective, constitutionally enshrined, equality protection doctrine that facilitates better government while enhancing the rights of certain individuals. A felicitous combination of factors including sophisticated legislation ${ }^{3}$ and an intellectually curious judiciary has gotten us off to a good start. As we move into the second decade and more closely explore the application of equality protection to the range of distinctions used by government in such things as benefit delivery programs and income taxation, this legislative and jurisprudential platform should serve us well.

That said, there are still important choices to be made. There is a middle ground that, in my opinion, is clearly preferable - what I call here the Canadian contextual solution. ${ }^{4}$ This middle ground is not yet secure, however. On both sides there are persuasive voices counselling interpretive methodologies that I believe are unpalatable.

To the right, there are the democrats. For this group, the distrust of democracy that takes political decision-makıng powers away from the legislature and confers them on 609; and Miron v. Trudel (1995), 124 D.L.R. (4th) 693.

3 Canadian Charter of Rights and Freedoms, part I of the Constitution Act, 1982, being Schedule B of the Canada Act, 1982 (U.K.), 1982, c. 11 [hereinafter the Charter].

4 By way of Executive Summary, the paper first adopts (L'Heureux-Dube J. might say hijacks) the contextual methodology most fully developed by her in Egan v. Canada and then proposes a range of contextual factors that seem to accommodate best the various community objectives and values in play in this type of $\mathrm{s} .15$ litigation. 
the judiciary is wrong-headed and without theoretical justification. ${ }^{5}$ While this group may rage against trivializing the Charter, ${ }^{6}$ that is a syllogism. The real concern is with trivializing the elected legislature.

To the left, there are those who see equality protection as inalienable ordnance that transcends the merely political. For this group, civil liberties are core values drawing legitimacy from a Natural Law wellspring. If threatened, these are rights to go to the barricades over: "Life, Liberty, the Pursuit of Happiness" and all that.?

Unfortunately, these two perspectives seem fundamentally antagonistic. They both deliver important contradictory messages that go to the heart of how we see our community. ${ }^{8}$ Indeed, much of the Canadian political and academic debate on

See generally John Hart Ely, Democracy and Distrust: A Theory of Judicial Review (Cambridge, Massachusetts: Harvard University Press, 1980). A leading Canadian academic in this camp is Peter Russell. See, e.g. P.H. Russell "A Democratic Approach to Civil Liberties" (1969) 19 U.T.L.J. 109 and "Standing Up for Notwithstanding" (1991) 29 Alta. L. Rev. 293. beginning at page 528 , building upon the spadework of Galligan $\mathrm{J}$. at trial in O.P.S.E.U. v. National Citizens Coalition Inc. (1987), 60 O.R. (2d) 26, supported on appeal to the Ontario Court of Appeal with references to the non-intrusive American experience ((1990), 74 O.R. (2d) 260)). Note the cursory dismissal of this argument by lacobucci J. in Symes v. M.N.R. (1993), 161 N.R. 243 (S.C.C.) beginning at page 308. See the discussion infra, Part III.C.1.

7 The 1968 Department of Justice proposal, A Canadian Charter of Human Rights, issued by Justice Minister Trudeau, provided the following introductory rationale: "In ancient times, and for centuries thereafter, these rights were known as 'natural' rights; rights to which all men were entitled because they are endowed with a moral and rational nature. The denial of such rights was regarded as an affront to 'natural' law - those elementary principles of justice which apply to all human beings by virtue of their common possession of the capacity to reason. These natural rights were the origins of the western world's more modern concepts of individual freedom and equality" (ibid. at 9).

The March 17, 1995 National Edition of the New York Times (dateline Princeton University) reported the following exchange between two of the equality protection lions (who speak for two very different ideological prides):

[U.S. Supreme Court Justice Antonin Scalia] said the problem began with the old commonlaw system in England, where judges, unconstrained by statutes or a written constitution, exercised the thrilling function of making law. From there it spread to modern law schools, where impressionable young students come away thinking that the highest function of a judge is 'devising, out of the brilliance of one's own mind, those laws that ought to govern mankind,' Justice Scalia said, exclaiming, 'what a kick'.

The only problem with that approach is 'a modern trend called democracy,' he said, adding, 'It is simply not compatible with democratic theory that laws mean whatever they ought to mean and that unelected judges decide what that is.'

Justice Scalia described himself as neither a "literalist" nor a "nihilist," but a "textualist," who believes that judges should apply the actual language of the Constitution and laws, reasonably understood, rather than search for deeper meaning or broader social purposes...

As an example of what is wrong with the Court's approach to statutory interpretation, Justice Scalia offered one of his favourite examples, a case from 1892, Church of the Holy Trinity v. United States. A church in New York that had brought a pastor over from England was fined for violating a Federal law that made it a crime to 'assist or encourage the importation or migration of any alien' into the country 'to perform labor or service of any kind'. The law made exceptions for artists, actors, domestic servants and a few others, but not for pastors.... 
constitutionally enshrined civil liberties has been fought on this terrain. ${ }^{9}$

It will be argued here that while both perspectives inform and illuminate, we are best served if neither prevails. For the political and judicial job at hand, theoretical vigour is a dangerous luxury. Better we should learn from both, paying obeisance to neither.

A retreat from rigour is normally the pursuit of the intellectually challenged. Here, however, I think we will see that some impressive authorities weigh in on the side of equivocation.

Having dispatched the theoretical purists, the second part of the paper will then seize the so-called middle ground and float a range of factors that implement a contextual analysis of the Income Tax $A c t^{10}$ and equality protection.

In the words of Leon E. Trakman,

The purpose is to do more than identify individual rights as they are: it is to contextualize them in light of their prospective social benefits and effects. It is to shift them from a narrow liberal conversation to a multi-faceted and human context within a participatory democracy."

All of which is interesting enough, but is there any utility in this exercise? I think there is, and offer the following Mission Statement:

[T]he Court said Congress could not have expected or intended a result that went against 'the whole history and life of the country'.

To Justice Scalia, the outcome was preposterous. 'The act was within the letter of the statute, and was therefore within the statute,' he said. 'End of case.'

Not so fast, Prof. Laurence H. Tribe of Harvard Law School said when his turn came to respond. There was a lot more to say about the Holy Trinity case. If artists and actors were exempted from the law while pastors were not, the law might amount to unconstitutional discrimination against religion in violation of the First Amendment.

Professor Tribe, a liberal, conceded that he was offering a late 20th century way of looking at the Holy Trinity case. But that was appropriate, he said. 'The interpreter's task is to do the best she can to figure out what the underlying rights and principles are, for each generation,' he said. 'In the end, no interpretive philosophy can save any of us from having to make hard choices'.

As with some of the best Canadian dust-ups, this one is reminiscent of the Hundred Year War. Mother Courage reports that nobody seems to have won, nobody (with the possible exception of René Lévesque) has been hurt and everybody is expecting victory once we have thoroughly canvassed the possibilities. As Joseph Weiler notes in "The Evolution of the Charter: A View from the Outside" in J.M. Weiler \& R.M. Elliot, eds., Litigating the Values of a Nation: The Canadian Charter of Rights and Freedoms (Toronto: Carswell, 1986) at 54, the Premiers (read democrats) thought they had secured final victory with the addition of the notwithstanding clause in the Summer of 1980 but the civil libertarian cottage industrialists then stole the field at the Parliamentary Special Committee in the fall of 1980 . The battle ground has now shifted from the political field to the judicial. Dale Gibson provides a recent war-zone update in "The Deferential Trojan Horse: A Decade of Charter Decisions" (1993) 72 Can. Bar Rev. 417. R.S.C. 1985, c.1 (5th Supp.) as amended. 
In twenty minutes the reader will be significantly better prepared to answer the following question: does our government unconstitutionally discriminate against the following classes of persons, for the reason stated:

1) natural parents, by providing additional U.I. benefits to adopting parents;

2) eighteen year old workers, by restricting the GST Credit to those nineteen and over;

3) custodial single parents, by moving the incidence of taxation on the income used to fund maintenance payments from the payor to the payee;

4) smokers and drinkers, by taxing their recreational consumables at a higher rate;

5) gays and lesbians, by: a) excluding them from the ambit of our human rights legislation; and b) excluding them from obtaining the status of spouse under the Income Tax Act,

6) aliens, by prohibiting lawyers from practicing their trade until they become Canadian citizens; and

7) women, by restricting child care expense deductions in the Income Tax Act.

\section{THE CANADIAN CONTEXTUAL SOLUTION}

\section{A. ANDREWS v. LAW SOCIETY OF BRITISH COLUMBIA ${ }^{12}$}

Unlike the U.S. Supreme Court, our Supreme Court has embarked on the judicial journey into constitutional equality protection with express hash marks leading back to certain intellectual bloodlines. ${ }^{13}$

On display in all three reasons for judgment in Andrews is the pragmatic wing of the Civil Liberties groundswell. ${ }^{14}$

Like Madison and Jefferson before them, ${ }^{15}$ once over the barricades, Justices

[1989] I S.C.R. 143 [hereinafter Andrews].

This is a gratuitous insult that is only justified if it helps communicate the fact that our equality protection jurisprudence is based on more substantial, explicitly cited, academic underpinnings than the surprisingly sparse underpinnings provided in the seminal U.S. cases. See e.g. United States v. Carolene Products Co., 304 U.S. 144 (1937) (famous footnote 4 of Justice Stone on page 152) and Brown v. Board of Education, I and II: 347 U.S. 483 (1953) and 349 U.S. 294 (1954). In Andrews there is no talk of Cicero, Aquinas, the American Declaration of Independence or the revolutionary-French Declaration of the Rights of Man and of the Citizen (the more radical elements of the civil libertarian heritage that are cited in Chapter I of $A$ Canadian Charter of Human Rights, Department of Justice, Justice Minister P.E. Trudeau, 1968).

Once over the barricades the American Age of Reason revolutionaries shelved "Life, Liberty and the Pursuit of Happiness" for a more prosaic vision of government based on institutional checks and balances. For these erstwhile civil libertarians, constitutional equality protection became part of the Bill of Rights afterthought. Rather than trash the process-driven ying and yang of the 1789 Constitution, the American revolutionaries (now government functionaries) relegated equality protection to what must have seemed a distinctly unpromising "due process" basket. See Ely, supra 
Wilson, McIntyre and LaForest seem more intent on applying the brakes than in exulting in the triumph.

Wilson J.'s judgment in Andrews begins by invoking three distinctly conservative equality protection solons: John Hart Ely, the author of the democrats' baedeker; ${ }^{16}$ U.S. Supreme Court Justice Stone, the father of the restrictive all-or-nothing American regime that limits real equality protection to a very few groups that historically have been subjected to highly suspect treatment; ${ }^{17}$ and John Stuart Mill, the utilitarian's civil libertarian. ${ }^{18}$

The message here from Wilson J. is, I believe, one of caution. While she, perhaps as enthusiastically as any Supreme Court justice, has been willing to ignite the equality protection powder, she has also most clearly identified the need to circumscribe its use. $^{19}$

McIntyre J. also lines up a surprisingly reticent cast of equality protection advocates. Early on, he quotes John H. Schaar to the effect that equality is a "protean" concept. ${ }^{20}$

note 5 at $88 \mathrm{ff}$.

Ely's Democracy and Distrust, ibid, promotes democracy as a core value while undermining such pretensions for equality protection. The book does for democrats what Milton Friedman's Capitalism and Freedom (Chicago: University of Chicago Press, 1962) did for neo-conservatives - it gives them intellectual legitimacy in readable snippets. For example, Ely dispatches the "Natural Law" argument in these terms:

It's not nice to fool Mother Nature, and even Congress and the President shouldn't be allowed to do so. The idea is a discredited one in our society, however, and for good reason.

'[A]ll theories of natural law have a singular vagueness which is both an advantage and disadvantage in the application of the theories'[reference omitted]. The advantage, one gathers, is that you can invoke natural law to support anything you want. The disadvantage is that everybody understands that. Thus natural law has been summoned in support of all manner of causes in this country - some worthy, others nefarious - and often on both sides of the same issue.

Even Laurence Tribe has rejected a core value/Natural Law type justification for constitutional equality protections. See L.H. Tribe, American Constitutional Law, 2d ed. (Mineola, N.Y.: The Foundation Press Inc., 1988) at 1-7; "The Majoritarian Difficulty" at 10; c. 8 at 560; and c. 16 at 1436. See footnote 52 and the text associated with that footnote. For an update on Democracy and Distrust see generally the collection of articles in (1991) 77 Virginia L. Rev., including Ely's contribution at 833. See Carolene Products, supra note 13, and the reference to a "discrete and insular minority" in footnote 4; for a useful discussion of footnote 4 see Ely, supra note 5 at 75 .

"It is proper to state that I forego any advantage which could be derived to my argument from the idea of abstract right, as a thing independent of utility. I regard utility as the ultimate appeal on all ethical questions; but it must be utility in the largest sense, grounded on the permanent interests of a man as a progressive being." J.S. Mill, On Liberty and Considerations on Representative Government, R.B. McCallum ed., (Oxford: Basil Blackwell, 1946) at 9.

In the continuing debate over the proper interpretation of the word "discrimination" in s. 15 of the Charter, it is Wilson J. who most clearly opts for an interpretation that uses the discrimination modifier as a real contraction of the section's ambit - serving to restrict the focus to those distinctions with roots based in prejudice. See the discussion of infra, Part III.C.4 under the heading "Community Prejudice as the Engine that Drives the Pre-emption of the Political Process." Andrews, supra note 12 at 164. See J. H. Schaar, "Equality of Opportunity and Beyond" in J.R. Pennock \& J.W. Chapman, eds., Nomos IX: Equality (New York: Atherton Press, 1967). 
Not knowing my Wordsworth, ${ }^{21}$ I originally thought that "protean" provided a cachet of importance, connecting equality with things seminal. In fact, Oxford provides these definitions:

A sea-god, the son of Oceanus and Tethys, fabled to assume various shapes,... Hence, allusively, One who, or that which, assumes various forms, aspects, or characters; a changing, varying or inconstant person or thing. ${ }^{22}$

In passing, McIntyre J. also refers to Aristotle's Nicomachean Ethics. Putting aside, for the moment, Aristotle's general vilification as the godfather of separate but equal, ${ }^{23}$ Nicomachean Ethics delivers another important introductory message. Aristotle is the patron saint of political equivocation. Like John Stuart Mill's introduction in On Liberty, the lecturer in Nicomachean Ethics begins by defusing expectations and dismissing those who claim to offer political science absolutes. For Aristotle, the precision of the answer must vary according to the nature of the area of study, and the ordering of public affairs is an imprecise enterprise at best. ${ }^{24}$ In politics, it was Aristotle who first said: "Not the right answer, stupid. The best answer."

The world is too much with us; late and soon,//Getting and spending, we lay waste our powers;/Little we see in Nature that is ours;/We have given our hearts away, a sordid boon!//...Great God! I'd rather be//A Pagan suckled in a creed outworn;/So might I, standing on this pleasant lea//Have glimpses that would make me less forlorn;/Have sight of Proteus rising from the sea://Or hear old Triton blow his wreathed hom. William Wordsworth "The World is Too Much With Us" [1806]. The Compact Edition of the Oxford English Dictionary (Oxford: Oxford University Press, 1981) at 2336.

See the discussion infra, Part III.C.6 under the heading "Weighing Adverse Effect Against Either Administrative Imperative or Conflicting Constitutional Imperative."

Our discussion will be adequate if it achieves clarity within the limits of the subject matter.

For precision cannot be expected in the treatment of all subjects alike, any more than it can be expected in all manufactured articles. Problems of what is noble and just, which politics examines, present so much variety and irregularity that some people believe that they exist only by convention and not by nature. The problem of the good, too, presents a similar kind of irregularity, because in many cases good things bring harmful results. There are instances of men ruined by wealth, and others by courage. Therefore, in a discussion of such subjects, which has to start from a basis of this kind, we must be satisfied to indicate the truth with a rough and general sketch: when the subject and the basis of a discussion consist of matters that hold good only as a general rule, but not always, the conclusions reached must be of the same order. The various points that are made must be received in the same spirit. For a well-schooled man is one who searches for that degree of precision in each kind of study which the nature of the subject at hand admits: it is obviously just as foolish to accept arguments of probability from a mathematician as to demand strict demonstrations from an orator.

Aristotle, Nicomachean Ethics, trans. M. Ostwald (New York: MacMillan Publishing Company, 1986) $1094 \mathrm{~b}$ beginning at line 11 . It should be noted that while McIntyre J. refers to Nicomachean Ethics, it is in passing and without adopting Aristotle's perspective. 
By way of peroration, like Wilson J., McIntyre J. relies on Stone J.'s limiting "discrete and insular minority" handle. ${ }^{25}$

LaForest $\mathrm{J}$. is in the unenviable position of being the sixth vote in a potentially hung jury. While his structural analysis is, I believe, the least adventurous of the three reasons for judgment in Andrews, and indeed, most sympathetic to the democrats' perspective, ${ }^{26}$ LaForest $\mathrm{J}$. avoids the spectacle of a tie by fitting this Oxford lawyer into one of the American highly suspect categories: landed aliens.

\section{B. EQUALITY PROTECTION IN BRITISH NORTH AMERICA: A LONG PRAGMATIC HISTORY}

There is a body of commentary that is now attempting to distinguish the American and Canadian equality protection experiences. ${ }^{27}$

The presence of French Canada, and the extraordinary challenge of protecting a French Catholic minority partner under siege, is an obvious distinction that separates the two countries. ${ }^{28}$ But beyond this, there is also what I would call the kinder and

McIntyre J.'s s. 15 analysis focuses on three radically different camps: on the right, McLachlin J.'s test of rationality (here speaking for the B.C. Court of Appeal in Andrews itself); on the left, Professor Hogg's conclusion that a simple distinction can send the matter on to section 1; and in the middle, Hugessen J. (see Andrews, supra note 12 at 178). As the elevated McLachlin J. notes in Miron v. Trudel, supra note 2 at 739, Justice Mcintyre opted for the middle ground.

Under the heading "consistency is the hobgoblin of small minds," while Professor Hogg appears to have gone right, Hugessen and McLachlin JJ. appear to have gone left. See P. Hogg, Constitutional Law of Canada, 3d ed. (Toronto: Carswell, 1992) especially at 33-21:

Does it make much difference whether the Court gives a wide interpretation to rights and relaxes the standard justification under $\mathbf{s .} 1$, or gives a narrow interpretation to rights and maintains the stringent standard of justification called for by Oakes? If we assume that the outcomes of cases will be much the same under either approach, the second approach is surely preferable, because it will reduce the volume of litigation and limit the policy-making role of the courts.

See also page 35-7. Passing Professor Hogg on their way left, see the Thibaudeau judgments of Hugessen J.A. (speaking for the majority of the Federal Court of Appeal) and McLachlin J. (in dissent at the Supreme Court of Canada). Further on the same hobgoblin theme, see also this author's democratic excesses in "Constitutional Equality Protections and the Income Tax Act. Equality vs. Equity" in Report of the 1994 Prairie Provinces Tax Conference, Canadian Tax Foundation.

LaForest J.'s subsequent equality protection judgments confirm his heightened deference towards the legislatures; see e.g. Schachter v. Canada, [1992] 2 S.C.R. 679 at 727; and McKinney v. University of Guelph, [1990] 3 S.C.R. 229 at $317 \mathrm{ff}$. In Egan v. Canada, supra note 2, he expressly raises the imprecision of Justice McIntyre's treatment of "discrimination" at 168 and 174 of Andrews (see beginning at page 620). See also infra note 87. Specifically, on the treatment of equality protections and the Income Tax Act, see e.g. the recent ruminations of Létoumeau J. in $R$ v. Lister (1994), 116 D.L.R. (4th) 637 (F.C.A.) at 642.

See references, infra note 35 . Many have commented on the split along gender lines in the recent equality protection decisions of the Supreme Court of Canada (see Thibaudeau, Egan and Miron). Of equal interest to me is the emerging French Canada/Alberta axis (Lamer C.J., LaForest, Gonthier and Major JJ.). Given the special francophone concern with a constitutional equality protection that may undermine the capacity of the French majority in Quebec to protect the French presence in North America and given the conservative distrust of the liberal glorification of civil 
gentler thesis; the idea that as a community, we have not been quite as bad as our southern neighbour.

I would dispute the utility of such self-congratulation. The relative historical virulence of our prejudices is a theology that will not save many souls.

What I would not dispute, however, is the fact that our equality protection history is different from the American one and that our history contains the seeds of a contextual approach that has served and will continue to serve us well.

All branches of government, not just the judiciary, are charged with interpreting and acting in compliance with constitutional equality protection. Section 15 of the Charter is an equal opportunity directive. ${ }^{29}$ Indeed, in Canada, government has traditionally used constitutional equality protection not just as a judicial buffer against executive and legislative excesses, but also as a means for the executive and legislative branches to foster the collaboration of potentially disaffected groups.

Nobody has played the equality protection card better than George III and his Parliament. In dizzying succession, The Royal Proclamation of $1763^{30}$ courted the "Nations of Indians," the Quebec Act, 1774" courted the "sixty-five thousand Persons professing the Religion of the Church of Rome" and the Constitutional Act, 179132 courted those new arrivals from the former colonies and Britain who required a local government they could control and the services of a "Protestant Clergy." Arguably discrete and insular minorities all.

George may have been mad, but he understood Canadian politics. Canadians regularly look to government to facilitate civil liberties, sometimes in ways that contrast sharply with American equality protection tenets.

liberties, it should come as no surprise that these four are providing the least expansive interpretation of s. 15. The political imperatives of French Canada and conservative Alberta are congruent, once again. As Brian Mulroney will tell you, this is one way to build a Canadian majority.

Laurence Tribe makes the point that the adversarial relationship between the judiciary on the one hand and the executive and legislative branches of government on the other, and the fact that the courts can trump another branch's contrary interpretation of a constitutional equality protection, tend to obscure the fact that all three branches (and not just the courts) are charged with meeting the same constitutional imperatives, and indeed, are often playing from the same playbook. See e.g. Tribe, supra note 16 at 16 . See also Section 17-3 of c. 17 subtitled "Due Process of Lawmaking and Due Process of Law-Applying" (ibid. at 1682). Statutes of Canada, Volume XII, Tab 12, No. 1. See paras. 12-19 (of 19).

$31 \quad 14$ Geo. 3 , c. 83 (U.K.) found in Statutes of Canada, Volume XII, Documentation, Tab 12, No. 2, a nifty piece of equality protection slight of hand that expressly repudiates both the Royal Proclamation of 1763 as well as Elizabeth I's Oath of Allegiance. See paras. IV, VII and XV (concerning prior approval by the executive branch of certain ordinances "touching Religion"). Note that at the same time that the American revolutionaries were working on a Declaration of Independence for their majority, the English were (arguably) creating the real declaration of independence for a truly discrete and insular minority: British French Catholics living in Quebec. 31 Geo. 3, c. 31 (U.K.) in Statutes of Canada, Volume XII, Tab 12, No. 3. See the establishment of Upper Canada and paras. XXXV-XLII. 
Religious freedom, always a handy equality protection litmus test, is a good example. The Age of Reason orthodoxy separating Church and State, so central to American equality protections, ${ }^{33}$ has no resonance at all in Canada. Rather than eschew the marriage of Church and State, we have embraced it, not as an agency for tyranny, but as a safer harbour for those under seige.

As Jennifer Nedelsky notes: "We [the Canadian community] recognize that the collective is a source of autonomy as well as a threat to it:.34 In broader strokes, Colleen Sheppard makes the point in these terms:

In the United States context, racial integration was an important component of the struggle towards racial equality. In Canada, however, we see precisely the opposite concem. The struggle for equality for francophone minorities outside of Quebec has been a struggle not for integration, which would spell assimilation, but for the right to education in separate schools. This example may also illustrate a greater receptivity in Canada to collective or group rights in contrast to what I argue is a predominantly individualistic approach in the United States. ${ }^{35}$

While Canadian prejudices are no less palatable than those of other western cultures, it seems fair to say that there is a distinctly Canadian way of dealing with them. It is pragmatic. $^{36}$ It is results oriented. ${ }^{37}$ It is multi-faceted. ${ }^{38}$ It need not be

33 See e.g. the first amendment to the U.S. Constitution [1791].

34 J. Nedelsky, "Reconceiving Rights as Relationship" (1993) 1 Rev. of Const. Studies 1 at 8.

35 C. Sheppard, "Equality in Context: Judicial Approaches in Canada and the United States" (1990)

39 U.N.B.L.J. 111. For high octane academic authorities see Ms. Sheppard's footnote 3 (excluded from quotation above) and the references to works by Gad Horowitz and S.M. Lipset. See also e.g. W.W. Black, "Intent or Effects: Section 15 of the Charter of Rights and Freedoms" in Weiler \& Elliot, eds., supra note 9 at 133.

36 The best historical primer on Canadian civil liberties is provided by the League for Social Reconstruction academic, activist and litigator Frank Scott. By way of summary, Mr. Scott has noted: "Our pre-Confederation history thus provides us with indications of the need to formulate civil liberties in Canada, not as a comprehensive and broad declaration of rights, but as specific solutions to practical problems." F. Scott, Civil Liberties and Canadian Federalism (Toronto: University of Toronto Press, 1961) at 16.

37 For a Canadian spin on the limitations of applying hard core civil libertarian philosophy willy nilly without a contextual modifier see M. Gold, "Moral and Political Theories in Equality Rights Adjudication" in Weiler and Elliot, eds., supra note 9 at 85.

See, by way of historical examples, Frank Scott's references in Civil Liberties and Canadian Federalism, supra note 36, to the basic democratic rights and freedoms of individual electors implicit in the Constitution Act, 1867 as considered, for example, by Duff C.J. in the Alberta Press case [1938] S.C.R. 100 (Scott, ibid. at 18) and the references to the federal power of disallowance of provincial laws (Scott, ibid. at 23). Laskin C.J., the constitutional law expert, who, like Scott, cut his liberal civil libertarian teeth in responding to provincial laws and actions that were hostile to the trade union movement, demonstrated a surprising reluctance to embrace the Charter as a revolutionary brave new world. As Dale Gibson notes: "The first time a Charter argument was advanced before [the Supreme Court] ... Laskin C.J. (who had been considered a civil-rights activist throughout most of his career) interrupted counsel with so many unsympathetic questions and comments that the argument was finally abandoned. Lawyers seemed "so mesmerized" by the Charter, the Chief Justice complained on that occasion, that they had lost sight of other constitutional considerations." (Gibson, supra note 9 at 420 ). 
conservative. ${ }^{39}$ It is successful. It is consistent with where the Supreme Court is heading in its interpretation of the Charter generally, and s. 15 in particular.

\section{INTERPRETING THE CHARTER AND THE INCOME TAX ACT, THE SUPREME COURT'S METHODOLOGY OF CHOICE: PURPOSE, EFFECT AND CONTEXT}

\section{Purpose and Effect}

In the mid-eighties Dickson C.J. established legislative purpose as the sine qua non for the interpretation of both the Income Tax Act as well as the Charter. ${ }^{40}$

The jury is still out, ${ }^{41}$ but in my opinion, the potential of purpose-based statutory interpretation is exciting. ${ }^{42}$ While I agree with Justice Scalia that the exercise should

See the text associated with infra note 89.

40 See $R$ v. Bronfman Trust (1987), 87 D.T.C. 5059 at 5064, 5066 and 5067. For Chief Justice Dickson, the identification of legislative purpose is at the heart of statutory interpretation. In the Charter context see $R$. v. Big M. Drug Mart, [1985] 1 S.C.R. 295. See generally B. Dickson, "The Role and Function of Judges" (June 1980) L.S.U.C. Gaz. 14 at 138. In Bon-Secours v. Communauté Urbaine de Québec (1995), 95 D.T.C. 5017 at 5023, Gonthier J. has recently codified the Rules of Interpretation for taxing statutes in the following terms:

Rule 1 - "The interpretation of tax legislation should follow the ordinary rules of interpretation";

Rule 2 - "A legislative provision should be given a strict or liberal interpretation depending on the purpose underlying it, and that purpose must be identified in light of the context of the statute, its objective and the legislative intent: this is the teleological approach";

Rule 3 - "The teleological approach will favour the taxpayer or the tax department depending solely on the legislative provision in question, and not on the existence of predetermined presumptions";

Rule 4 - "Substance should be given precedence over form to the extent that this is consistent with the wording and objective of the statute";

Rule 5 - "Only a reasonable doubt, not resolved by the ordinary rules of interpretation, will be settled by recourse to the residual presumption in favour of the taxpayer."

¿ See infra note 58.

42 It is also the power source that will, I believe, bring order to the troublesome grouping exercise that continues to confound equality protection jurists. Is Suzanne Thibaudeau a single custodial parent whose treatment is to be compared with non-custodial parents, or is she part of the legally separated family whose treatment is to be compared to united two parent families? Is her status as female relevant, raising the issue of comparing the treatment of single custodial mothers to noncustodial fathers? How you classify is how you will determine these cases. The methodology, I believe, must improve in terms of providing a rational basis for classification. For an interesting spin on the grouping issue see N. Iyer, "Categorical Denials: Equality Rights and the Shaping of Social Identity" (Fall 1993) 19 Queen's L.J. 179: "In order to succeed in an anti-discrimination claim in law,... the claimant must present a caricature of the individual or group's social identity distorting the individual and communal experience ... into a static and oversimplified image of the claimant's 'difference.' In this cartoon ... one social characteristic assumes gigantic proportions while other aspects of social identity are rendered indistinguishable from the background norm." (ibid. at 192). In the words of an earlier Albertan: "The inescapable answer is that we must look beyond the classification to the purpose of the law." J. Tussman \& J. tenBroek, "The Equal Protection of the Law" (1949) 37 Cal. L. Rev. 341 at 346. (See infra note 94 and Tarnopolsky J.'s 
not provide the excuse to rewrite the law, as a self-styled "textualist," even he seems to accept the utility in "reasonably understanding" the legislative tract. ${ }^{43}$

In a market economy democracy, income taxation is a primal exercise. As Report \#10 of the Royal Commission on Taxation noted:

[T] he personal income tax can allocate the tax burden in accordance with the twin ideologies of equity and ability to pay; at the same time, it is able to raise a large proportion of the national revenue, and also to redistribute wealth. ${ }^{4}$

Like the swallows to Capistrano, each Spring (since 1916) Parliament has almost invariably reassembled and reconsidered our taxation of income. During the Diefenbaker/Pearson Age of Reflection, the Royal Commission on Taxation provided an internationally recognized primer on income taxation. ${ }^{45}$ The House of Commons Standing Committee on Finance specializes in the subject. The Senate Banking Committee has responded impressively to important Finance Department initiatives like the 1969 White Paper on Tax Reform and the 1990 proposals for GST. ${ }^{46}$ The Tax Court of Canada (and before it the Federal Court - Trial Division, the Tax Review Board and the Tax Appeal Board) specializes in income taxation. The Canadian Income Tax Research Index ${ }^{47}$ provides an index of at least twenty-eight Canadian publications that are dedicated primarily to income tax law.

discussion of the role of this article in Re Catholic CAS, [1989] 69 O.R. (2d) 189 (see especially the footnote at page 205 of the reasons for judgment)).

See supra note 8.

Report of the Royal Commission on Taxation, Report No. 10, Taxation of the Family (Ottawa: Queen's Printer, 1967) at 1.

is Almost ten years after its publication, one of the leading U.S. tax academics, in an influential article, quoted at length from the Carter Commission Report (see B. Bittker, "Federal Income Taxation and the Family" (1975) 27 Stanford L. Rev. 1389 at 1393). See generally N. Brooks, ed., The Quest For Tax Reform: The Royal Commission on Taxation Twenty Years Later (Toronto: Carswell, 1988).

For example, both the House Finance, Trade and Economic Affairs Committee (see e.g. the Report to the House on the White Paper, October 5, 1970, Minutes of the Standing Committee beginning at page 93:14) and the Senate Committee on Banking, Trade and Commerce (see e.g. The Minutes of the Proceedings of the Senate Banking, Trade and Commerce Committee on the Proposals for Tax Reform in June of 1970 and the Committee's Parliamentary Report on the 1971 Tax Reform Legislation, November 4, 1971, Minutes of the Standing Committee beginning at page 47:1) held extensive hearings, backed by a professional staff, heard from Finance Department and other witnesses, and in the case of the Senate, published the written submissions from a variety of organizations (see the Senate Committee's Minutes of the Proceedings on the Proposals for Tax Reform, with submissions to the Committee regularly annexed). In contrast, the statements in the House or Senate proper (either in Committee of the Whole or otherwise) tend to pander to special interest groups or political motherhood and, from my experience, are seldom of much help. See e.g. the House of Commons debate (including section by section review by the Committee of the Whole after second reading) of tax reform in the Fall of 1971. McLachlin J.'s efforts at "Legislative History" in Thibaudeau (supra note 2 at 506) are, I believe, unsatisfactory, because they do not begin to tap the usual sources such as the Royal Commission on Taxation, which studied the taxation of the family in detail.

(Don Mills, Ontario: CCH Canadian) (looseleaf service). 
Accordingly, the Income Tax Act has a pedigree like no other legislation. Given the density of the text, the importance of the exercise and the complexity of the issues on the table, undue reliance on a plain meaning interpretation seems to me second rate. It fails to take advantage of the work of the legislation's numerous stakeholders, those who have contributed to its evolution over time, and by way of rational residue have left an express trail setting out their perceptions of the problems and the reasons behind the legislative changes at hand ${ }^{48}$ More importantly, interpretation by plain meaning rote diminishes the capacity and obscures the obligation of the tax courts

to work with the legislature to develop good tax laws ... to avoid the necessity for numerous technical loophole closing amendments ... [and to] interpret the tax statute fairly and equitably to give effect to the legislative scheme. ${ }^{49}$

Section 15 of the Charter provides a different imperative for a purposive interpretation. Protean concepts like equality and discrimination do not speak for themselves. They find meaning only once the purpose and effect of the impugned action is understood.

In Big $M$ Drug Mart Dickson C.J. proposes an analysis that focuses on the purpose and the effect of both the impugned legislation as well as the specific Charter provision:

In my view, both purpose and effect are relevant in determining constitutionality; either an unconstitutional purpose or an unconstitutional effect can invalidate legislation. All legislation is animated by an object the legislature intends to achieve. This object is realized through the impact produced by the operation and application of the legislation. Purpose and effect respectively, in the sense of the legislation's object and its ultimate impact, are clearly linked, if not indivisible. Intended and actual effects have often been looked to for guidance in assessing the legislation's object and thus, its validity.

Moreover, consideration of the object of legislation is vital if rights are to be fully protected. The assessment by the courts of legislative purpose focuses scrutiny upon the aims and objectives of the legislature and ensures they are consonant with the guarantees enshrined in the Charter.

In my view this analysis is to be undertaken, and the purpose of the right or freedom in question is to be sought by reference to the character and the larger objects of the Charter itself, to the language chosen to articulate the specific right or freedom, to the historical origins of the concepts enshrined, and where applicable, to the meaning and purpose of the other specific rights and freedoms with which it is associated within the text of the Charter. The interpretation should be, as the judgment in Southam emphasizes, a generous rather than a legalistic one, aimed at fulfilling the purpose of the guarantee and Rummaging in the Ashcans of the Legislative Process" (1995) 74 Can. Bar Rev. 1. 
securing for individuals the full benefit of the Charter's protection. At the same time it is important not to overshoot the actual purpose of the right and freedom in question, but to recall that the Charter was not enacted in a vacuum, and must therefore, as this Court's decision in Skapinker illustrates, be placed in its proper linguistic, philosophic and historical contexts. ${ }^{30}$

\section{Context}

Charged with the obligation of basing their interpretation of complex legislation like the Charter and the Income Tax Act on the squishy foundation of purpose and effect, our Supreme Court has sensibly adopted a squishy methodology that can accommodate such an imprecise mandate. Aristotle would approve. The code word is context. As L'Heureux-Dube' J. notes in Seaboyer:

It is my view that the constitutional questions must be examined in their broader political, social and historical context in order to attempt any kind of meaningful constitutional analysis. The strength of this approach was discussed by Wilson J., in Edmonton Journal v. Alberta (Attorney-General) (1989), 64 D.L.R. (4th) 577. She states at pp. 383-4 that, "[o]ne virtue of the contextual approach, it seems to me, is that it recognizes that a particular right or freedom may have a different value depending on the context." "nt

If purpose, effect and context are to be the New Jerusalem in constitutional interpretation, how then is our judiciary to fashion a successful approach to constitutional equality protection and its application to something like the Income Tax $A c t$ ? The remainder of this paper will address this question.

\section{APPLYING CONSTITUTIONAL EQUALITY PROTECTION TO THE INCOME TAX ACT}

\section{A. BENEFITTING FROM THE AMERICAN EXPERIENCE: TRIBAL SENSITIVITY}

While the Americans have developed equality protection processes that are foreign to the Canadian experience, the foundational problems and objectives for both countries are essentially the same. Accordingly, it should come as no surprise that both countries are heading in the same direction. Indeed, Laurence Tribe's proposed Model VII might be read as a codification of our own Supreme Court's contextual efforts.

$R$ v. Big $M$ Drug Mart Lid., supra note 40 at 331,344 . Note L'Heureux-Dubé J.'s call for a return to purposive basics in Egan v. Canada, supra note 2 at 629.

s1 $\quad R$ v. Seaboyer (1991), 83 D.L.R. (4th) 193 at 204. See also $R$ v. D.O.L., [1993] 4 S.C.R. 419 at 438, L'Heureux-Dubé J.; Symes v. Canada (M.N.R) (1993), 161 N.R. 243 (S.C.C.) at 334, Iacobucci J.; Egan \& Nesbit v. Canada (1993), 153 N.R. 161 (F.C.A.) at para. 65, Robertson J.A.; at para. 83, Mahoney J.A.; and at paras. 104, 105, 129-131, Linden J.A. (in dissent). See, again, L'Heureux-Dube J. in Egan v. Canada, supra note 2 at 646 and Gonthier J. in Miron v. Trudel, supra note 2 at 703 . See generally the various contextual approaches of Marshall, Brennan JJ. and Burger C.J. in the difficult equality protection case, Phyler v. Doe, 457 U.S. 202 (1982) (Texas prohibition against school boards using state funds to educate illegal alien children). 
Having catalogued six models that have been used as the basis for American constitutional interpretation over the last two centuries, Tribe proposes his own pragmatic Model VII:

Rather than routinely treating freedom as best preserved, whatever the context, by strict separation of powers and federal-state division, as in Model $\mathbf{l}$, or routinely treating it as best advanced, again whatever the context, by placement of specific subjects beyond governmental control, as in Models II and V, a model consciously concerned with contextually matching decisional structures to substantive ends - Model VII - might perceive freedom as best served in some contexts by putting a matter beyond governmental reach, and in others by precisely the opposite approach. This model would distill from all the others what is often a poorly disguised secret: that "neutral" principles of structure are worth embracing as constitutional precepts only to the extent that the substantive human realities they bring about help fulfil the constitutional design and that each prior model proved empty exactly to the degree that it sought to deny this truth..$^{32}$

In these contextual sweepstakes, given the sophistication of our legislation (the Charter), the intellectual curiosity of our judges and the drag of the all-or-nothing historical baggage in the States, it seems reasonable to suggest that Canadians should develop a comprehensive contextual methodology for constitutional equality protection first. ${ }^{33}$ That said, it is still the Americans who have wrestled with Proteus over the long haul, and it would be self-deluding to think that those who have monitored this particular war zone for so long have not come away with important tactical insights. This is especially true if we accept that the best answers develop out of an empirical process of trial and error rather than as a bolt of truth from Olympus.

Indeed, most of the contextual factors to be proposed here have been studied in detail, in one way or another, in the States. We can benefit from some attention to that experience.

\section{B. THE PURPOSIVE AND CONTEXTUAL APPROACH MAKES NEW DEMANDS ON OUR JUDICIARY: THE JUDGE AS DECATHLETE}

Before proposing a range of contextual factors for the application of $\mathrm{s} .15$ of the Charter to the Income Tax Act, there is a final issue of process to discuss.

See Tribe, supra note 16, c. 17 at 1673: "Model VIl - Toward a Model of Structural Justice." Like Mill and Aristotle, Tribe studiously avoids the higher octane Natural Law type justifications for equality protections. Notwithstanding the intellectual consternation that followed publication of Ely's Democracy and Distrust, supra note 5, the second edition of Tribe's American Constitutional Law text book continues to avoid the esoteric theoretical justification and sticks with the prosaic pigeons: "In their article on 'Impulse Control in Pigeons,' the experimenters conclude that even pigeons seem capable of leaming to bind their 'own future freedom of choice' in order to reap the rewards of acting in ways that would elude them under the pressures of the moment" (Tribe, ibid. at 11). years of American experience with "due process" and one hundred years' experience with "equal protection" of the law. See 5th (1791) and 14th (1868) Amendments to the U.S. Constitution. 
If the equality protection methodology is to rely on a judicial assessment of legislative purpose and effect, this is not judicial business as usual. The evidence required $^{54}$ and the willingness and capacity of our courts to consider things like politics, philosophy, sociology and economics present extraordinary new challenges. The judge who is straining to retreat to process that is familiar is the judge who will fail.

Ten years ago the Master of the Rolls told a Canadian audience that the issue raised by $\mathrm{s}$. 1 of the Charter was "scarcely justiciable" and "Indeed I wonder whether something may not have gone wrong."ss

The Right Honourable Sir John Donaldson MR would not be my first choice for judge. There is no doubt that the purposive and contextual analysis introduced by Dickson C.J. ten years ago, and now installed as part of the Supreme Court's accepted methodology, is troublesome. For issues as nuanced and complex as constitutional equality protection and the implementation of equitable and progressive income taxation, our judges need to turn it up a notch. Happily, there are those who see judges playing an effective role notwithstanding the obvious limitations of the trade. For example, Guido Calabresi notes:

My second, obvious presupposition is that there are things which courts selected, trained, protected and staffed (or better, non-staffed) as they are, do well and things they do not do well. For example, courts do not have a special skill at sensing directly what a majority of the people want, while they do have substantial skill at discerning how others have treated similar situations.

This does not mean that courts should not do what they cannot do well if: 1) other law making institutions cannot do it even that well or cannot do it at all; or 2) if other law making institutions cannot do well what courts can do well and the two roles are inextricably linked in that political system. For example, if the law were what Dick Posner (before his lateral transfer to the bench) thought it was, all judges should be economists; if it were what Ron Dworkin says it is, all judges should be philosophers. In fact, law is much more than what Posner and Dworkin say it is, and hence most philosophers and economists would make terrible judges. But this does not mean that judges should ignore philosophy or economics in their decision making - just because others are better at these disciplines than they are. Courts may be best at the combined task and hence, like competitors in the decathlon, must attempt some things which others could do better. ${ }^{56}$

See infra note 58.

The Right Honourable Sir John Donaldson MR, "The Judiciary, the Legislature, the Executive and Politics," in F. E. McArdle, ed., The Cambridge Lectures 1987, Selected Papers at the Conference of the Canadian Institute for Advanced Legal Studies, 1987, held at Cambridge University, England (Montreal: Les Editions Yvon Blais, 1989) at 325-26.

G. Calabresi, "Too Much, Too Little, or Both: Some Thoughts on Law Making by American Courts" in E.G. Baldwin, ed., The Cambridge Lectures 1983, Selected Papers Based upon Lectures Delivered at the Conference of the Canadian Institute for Advanced Legal Studies held at Cambridge University, England (Toronto: Butterworths, 1985) at 1. For two other sensible ruminations see A. Cox, "The Role of the Supreme Court in American Society" (1967) 50 Marquette L. Rev. 575 and R.S. Abella, "Public Policy and the Judicial Role" (1989) 34 McGill L.J. 1021. See also B.M. McLachlin, "The Role of the Court in the Post-Charter Era: Policy Maker or Adjudicator?" (1990) 39 U.N.B.L.J. 43. 
The decathlon analogy is a good one. Our courts must understand that some new events have been added and they cannot expect to win if they refuse to participate in these events.

To give meaning to Dickson C.J.'s purposive methodology our courts must consider the "broader political, social and historical context.." ${ }^{17}$ In my opinion, this requires the delivery of sophisticated liberal arts-type evidence. ${ }^{58}$

\section{SOME CONTEXTUAL FACTORS THAT ASSIST \\ IN APPLYING CONSTITUTIONAL EQUALITY PROTECTION TO THE INCOME TAX ACT}

\section{Is Income Taxation Too Complex for the Courts to Scrutinize Under Constitutional Equality Protection?}

Beginning almost a century ago, the Supreme Court of the United States used the individual's constitutional right to due process ${ }^{59}$ to strike down a broad range of Progressive $^{60}$ social welfare legislation. ${ }^{61}$

See text associated with supra note 51 .

The composition of the evidence going to legislative purpose and effect and the mode of its delivery at trial remain problematic. See $R$ v. Heywood (1995), 174 N.R. 81 at 107 (S.C.C.), Cory J.: "The admissibility of legislative debates to determine legislative intent in statutory construction is doubtful." At two recent meetings of the Constitutional Law Subsection of the Canadian Bar Association (Northem Alberta), in separate appearances, both former Supreme Court Justice Stevenson and Alberta Court of Appeal Justice Côté voiced a distrust of legislative history and legislative effect-type evidence. In my opinion, this type of evidence is crucial in more difficult Charter and Income Tax Act litigation. By definition, however, the evidence is untrustworthy. The best safeguard to ensure that it is properly vetted and challenged is, I believe, notice; and I would welcome rules that require that such evidence be provided to opposing counsel well before trial. I do not think that it is feasible to rely on witnesses to either deliver this material as oral evidence or be available to comment on the material submitted. The Report of the Royal Commission on Taxation speaks for itself and the best testing of this material by the opposing party is contradictory written material offered by opposing counsel, oral evidence in response or opposing counsel's argument. Opening the issue of the legislation's purpose and effect at the argument stage is too late; it reeks of purposive ambush and should unsettle even the most teleologically bent judge.

"[N]or [shall any person] be deprived of ... property, without due process of law;..." 5th Amendment [1791], Constitution of the United States of America; "nor shall any State deprive any person of ... property, without due process of law; nor deny to any person within its jurisdiction the equal protection of the laws...." 14th Amendment [1868], Constitution of the United States of America. See generally Tribe, supra note 16, c. 8, "Model II - the Model of Implied Limitations on Government: the Rise and Fall of Contractual Liberty," and see especially subheading 8-2, "The Lochner Era: Model II Triumphant" at 560. The capitalized reference is to the Progressive movement in the States at the turn of the Century.

61 For example, the New York legislature's attempt at establishing a maximum sixty hour work week for bakers was struck down in Lochner v. State of New York, 198 U.S. 45 (1905); 25 Supreme Court Reporter 539. 
The Lochner-era Court was second to none in its willingness to reverse the elected branches of government. ${ }^{62}$ Notwithstanding the ideological imperative, these laissezfaire jurists left the recently enacted progressive income tax legislation alone. Boris Bittker has commented on this uncharacteristic deference in these terms:

Surprisingly, however, even in the heyday of the judicial use of the due process clause to oversee legislation regulating private business, the Supreme Court virtually deprived it [the due process clause] of any jurisdiction over the federal taxing power, stating in Brushaber v. Union Pacific Railroad, 240 U.S. 1 (1916) that "the Constitution does not conflict with itself by conferring upon the one hand a taxing power and taking the same power away on the other by the limitations of the due process clause."[p. 24] To be sure, the Court went on to say that the courts could intervene if the taxing provision "was so arbitrary ... that it was not the exertion of taxation but a confiscation of property" $[p$. 24], but this reservation of a residual judicial function in extreme cases became a virtual dead letter....

I know of no detailed examination of this phenomenon in the tax field, but, in my opinion, it may well reflect the very complexities that we regularly deplore in the federal income tax and that have been integral features of the Code for many years. To paraphrase a hoary comment about grand opera, the Internal Revenue Code is not what it used to be - and never was. We regularly describe distinctions drawn by the Code as "unwarranted," "unjustified," or "inequitable," and before long the rhetoric has escalated and we find ourselves using adjectives like "absurd," "ridiculous," or "outrageous." Labels like these are pretty close to "arbitrary," "capricious," and "confiscatory" - terms that in the 1920s and 1930s, might have tempted the courts to hold the offending provisions unconstitutional.

Yet the courts did not intervene, even while they were holding that numerous regulatory statutes violated the due process clause. In my opinion, the courts sensed that the federal income tax - even in an earlier day - was so full of debatable distinctions that any attempt to police the Code in the name of substantive due process would lead them from one provision to another in a neverending process of judicial review. The result would be, as the cases moved up to the Supreme Court that the federal judiciary would begin to resemble the House Ways and Means Committee and the Senate Finance Committee - or perhaps a conference committee in perpetual session. ${ }^{63}$

In the words of Holmes J. (dissenting in Lochner itself):

The 14th amendment does not enact Mr. Herbert Spencer's Social Statics.... [A] Constitution is not intended to embody a particular economic theory, whether of paternalism and the organic relation of the citizen to the state or of laissez faire. It is made for people with fundamentally differing views, and the accident of our finding certain opinions natural and familiar, or novel, and even shocking, ought not to conclude our judgment upon the question of whether statutes embodying them conflict with the Constitution of the United States.

Lochner, ibid. at 546 (cited to Supreme Court Reporter).

B.I. Bittker, "Constitutional Limits on the Taxing Power of the Federal Government" (1987) 41

Tax Lawyer 3 at 11. B. Bittker is also the author of "A Comprehensive Tax Base as a Goal of Income Tax Reform" (1967) 80 Harv. L. Rev. 925 referred to with favour by Linden J. in Schachtschneider v. Canada (M.N.R.), [1993] 154 N.R. 321 (F.C.A.) (at paras. 35 and 61) and the author of "Federal Income Taxation and the Family" (1975) 27 Stan. L. Rev. 1388, quoted at length by Létourneau J. in Lister v. Canada (1994), 116 D.L.R. (4th) 637 at 653 (F.C.A.). See also Tribe, supra note 16 at 567. 
In the United States, the Supreme Court still refuses to subject income taxation to either due process or equality protection scrutiny ${ }^{64}$ In Canada, a similar judicial reluctance developed under the catchy code phrase: "trivializing the Charter."

Iacobucci J., the tax practitioner's Supreme Court justice, has now dispatched the trivializing doctrine without reservation (and without reference back to its American roots). ${ }^{66}$ Accordingly, with Symes, we are now firmly embarked on the complex exercise of subjecting the Income Tax Act to meaningful equality protection scrutiny.

As with much of the Charter evolution, this exercise is likely to be an empirical one. The courts should benefit from the episodic nature of litigation, establishing, as they go, contextual factors that help define the parameters of a successful equality protection review process for the Income Tax Act. $^{67}$

In any event, contextual (and chastening) factor number one is the complexity of the challenge. While we need not, perhaps, be as timorous as the Americans, we should not underestimate the complexity of the challenge ahead. The remainder of this paper focuses on other contextual factors that may prove important to the exercise.

2. The Purposive Starting Point Suggested in Stubart:

Begin by Identifying Which of the Three "State Interests" are in Play

Not all provisions of the Income Tax Act are created equal. As Estey J. notes parenthetically in Stubart, the Income Tax Act is complex legislation with three basic public policy objectives, or what he calls "state interests." These are:

1) the raising of revenue to fund government;

2) the achievement of equity among taxpayers in the raising of that revenue; and

3) the achievement of fiscal and social policies unrelated to the raising of revenue. ${ }^{68}$

For the case references see Lister v. Canada, [1994] 116 D.L.R. (4th) 637 at 644 . See Tussman $\&$ tenBroek, supra note 42 at 368,68 n.

See supra note 6. See generally F. Woodman, "The Charter and the Taxation of Women" (1990) 22 Ottawa L. Rev. 625 at 660.

See Symes, supra note 51 at 308. See Thibaudeau, supra note 2 at paras. 6 and 57, L'Heureux-Dube J.

There seems to be a "softening" of the Supreme Court's position on so-called benefit legislation, especially in the context of s. 1 and the Oakes test ( $R$ v. Oakes, [1986] 1 S.C.R. 103). See e.g. $R$ v. Edwards Books, [1986] 2 S.C.R. 713; Irwin Toy v. Quebec, [1989] 1 S.C.R. 927; $R$ v. Chaulk, [1990] 3 S.C.R. 1303 at 1341. In the context of legislation intended to assist a less advantaged group see Wilson J. in McKinney v. University of Guelph, [1990] 3 S.C.R. 229 at 401, 404.

Stubart v. The Queen, [1984] 84 D.T.C. 6305 at 6321, 6322. For example at 6322: "Whether the development [of doctrines of statutory interpretation] be by legislative measure or judicial action, the result is a process of balancing the taxpayer's freedom to carry on his commercial and social affairs however he may choose, and the state interest in revenue, equity in the raising of the 
If the tax provision under equality protection scrutiny either serves as an important part of the normative tax structure (state interest one) or implements taxpayer equity, the importance of the legislative objective should significantly constrain the judicial scrutineers. If, on the other hand, the provision falls within state interest three, such constraints may be minimal. ${ }^{69}$

For example, in Lister (the case that raises the constitutionality of the arbitrary cutoff of the GST Credit to those under age 19), a majority of the Federal Court of Appeal adopted the purposive approach. Létourneau $J$. found that the purpose of the GST Credit was to provide relief to lower-income Canadians from the regressivity of the consumption tax (the GST). He noted that this purpose fell within Estey J.'s second state interest; and accordingly, he proceeded to dispatch the Appellant's enumerated equality protection claim with some gusto:

\footnotetext{
Furthermore, when one looks at the larger context to determine whether the differential treatment created by the impugned provision amounts to discrimination within the meaning of section 15 , one finds oneself in a complex social, political, legal, fiscal and economic environment where Parliament is, in the State's interest, trying to raise revenues to fund government, achieve equity among taxpayers in so doing and implement fiscal and social policies unrelated to the raising of revenue. ${ }^{70}$
}

\section{Achieving Equality Without Unduly Sacrificing Equity}

The concepts of equality and equity are not synonymous. Equality is what Nellie McClung and Martin Luther King were after. Equity is what Kenneth Carter was after.

It may well be that certain distinctions in the Income Tax Act fail the emerging contextual test, and in particular, betray a legislative animus towards groups like women, gays and lesbians. In these circumstances, distrust of democracy may be sufficiently confirmed to countenance a pre-emptive strike by the judiciary.

If, however, we are entering an era in which the Income Tax Act is to be tested primarily on the basis of whether the court feels that a particular enumerated or analogous group is being treated "fairly"; we are, I believe, in for a bumpy ride.

Equality uber alles is a recipe for enhanced vertical and horizontal inequity. While the lot of a particular enumerated or analogous group may be improved, the lot of the rest of us, and in particular the lot of the poor, may well suffer. The remedies proposed by the dissenters in Thibaudeau and Symes are aggressively regressive. The Thibaudeau remedy would allow separating taxpayers to contract out of taxable income, and as with the proposed unlimited child care deductions in Symes, the wealthier the taxpayer the more generous the effect on taxable income. 
For those who assume that the achievement of vertical and horizontal equity in an income taxation regime is a simple affair their re-education should begin with the Report of the Royal Commission on Taxation, 1966; specifically, chapters 7 through 10: "Taxation Based on Ability to Pay," "Basic Features of the Comprehensive Tax Base," "The Present and Proposed Tax Systems" and "The Tax Unit." "71 Linden J. in Schachtschneider ${ }^{72}$ has provided a bibliography of some of the leading U.S. articles that discuss and build upon the analytical platform provided by the Royal Commission Report and that confirm the complexity of devising equitable definitions for the taxation units.

Equality protection is just that. It may or may not advance the lot of the meek. We should not, I believe, be unduly smitten by its progressive veneer. Bad things can come in good packages.

Real progressives neither eat quiche nor spend much time raging against discrimination. They deal directly with the imperative of a social inversion: "Blessed are the meek for they shall inherit the earth."

The presumption that I accept is that $\mathbf{s} .15$ of the Charter is progressive legislation. That said, in my opinion, the presumption is rebuttable, and there are enough troubling factors out there to give pause.

Some of the first serious claimants under s. 15 of the Charter seem far removed from an untouchable caste. Mr. Andrews is an Oxford-trained lawyer. Ms. Symes is a Bay Street lawyer. The Listers are the children of an Alberta Bencher. If these people need an underground railway, it is only to get them to the café at Holts.

Harry Glasbeek has suggested that rather than advance the cause of the modern state, the Charter generally has too often provided yet another neo-conservative nail in the welfare state's coffin, giving primacy to the individual private actor over the collective state. In Glasbeek's words: "[T]he state has inhibited itself."174

Specific to equality protection, the American experience serves to remind us that "equal protection" is closely related to the Lochner era's favourite conservative water boy: "due process." Indeed, given the restrictive wording of the 14th Amendment, ${ }^{75}$ these two constitutional handles have been used interchangeably, one in response to the prejudice of state government, the other to import the equal protection imperative into the scrutiny of federal action. ${ }^{76}$

11 Supra note 44.

$n \quad$ Supra note 63.

nThe Holy Bible, King James' Version, Matthew 5:5.

74 "The Social Charter: Poor Politics for the Poor" in J. Bakan \& D. Schneiderman, eds., Social Justice and the Constitution (Ottawa: Carleton University Press, 1992) at 116. See also J. Fudge, "Labour, the New Constitution and Old Style Canadian Liberalism" (1988) 13 Queen's L.J. 61.

is See supra note 59.

76 See Tribe, supra note 16 . See generally c. 16 and especially 13 n. 
People are judged by the company they keep (a contextual analysis for sure). While the 14th Amendment introduces constitutional equality protection, it also reaffirms due process, and (true to American constitutional form) repeats the constitutional prohibition against depriving persons of the "p" word."

All of which is not to cancel the parade, but given the conservative bloodlines, a dose of Glasbeekian skepticism seems politically sensible if not correct.

Indeed, in my opinion, the equitable identification of "economic power" (one of the Royal Commission's favourite phrases ${ }^{78}$ ) and the progressive taxation of such economic power eclipses the promotion of equality protection and any equality protection analysis must accommodate these other seminal policy concerns.

4. Community Prejudice as the Engine that Drives the

Pre-emption of the Political Process: The Need to Find Discrimination

The discrimination modifier in s. 15 is now attracting increased scrutiny. In the words of L'Heureux-Dube' J.:

I am led inevitably to the conclusion that a truly purposive approach to section 15 must place

"discrimination" first and foremost in the Court's analysis."

I agree with L'Heureux-Dubé J. But why should we focus on the discrimination issue? The process here is widely misunderstood. Our objective in constitutional equality protection is not to eradicate prejudice in legislators. Rather we are seeking a reliable warning system that confirms that distrust of democracy in particular circumstances is sufficiently established to justify reliance on the draconian remedy of anti-democratic judicial preemption. Discrimination therefore is a surrogate, the canary in the coal mine (or perhaps, in this case, the pigeon). ${ }^{80}$

The preemption of democracy is not something we can take lightly. By transferring equality protection decision-making from the legislators to the judges we not only pervert the democratic ideal, ${ }^{81}$ perhaps of greater concern, the political marketplace and its disparate convention of interested Canadian stakeholders, cannot worry the problem to resolution. Not only does the process lose the valuable input of the various

\section{Supra note 59.}

Report of the Royal Commission on Taxation, supra note 44, vol. 2, c. 1 at 10: "Objectives of the Tax System."

Egan v. Canada, supra note 2 at 637. While L'Heureux-Dube J. seems closest to the Wilson orthodoxy on an interpretation of discrimination in s. 15 , she has not taken that analysis to the limiting extent that is suggested here.

See supra note 52.

Seven years after the end of the Cold War, democracy as a community-ordering ideal is taking its lumps. Indeed, as several commentators have now mentioned, the values Canadians hold dear as a community are varied and not restricted to democracy. See authorities cited in supra notes $\mathbf{3 5}$ through 38 . 
stakeholders, these stakeholders have a reduced connection to, and responsibility for, a judicial resolution that is not of them. ${ }^{82}$

There may still be equality protection imperatives that the judiciary can safeguard better than the legislature. ${ }^{83}$ Judicial equality protection is, however, a remedy of last resort, and in my opinion, we want our discrimination canary to be as robust as reasonably possible.

Constitutional equality protection has been called a judicial trump. The Bridge analogy is useful but I would characterize $s .15$ as a judicial preemptive bid.

In Bridge, the preemptive bid is a good one, but only if the suit is long and weak. And weakness is the key. If there is any strength at all, better you should tarry in the lower conventions. That exploratory auction will expose the strengths and weaknesses of everybody and provide your side with the information necessary to secure the best contract. You only bid preemptively if you have no hope of doing any better.

Similarly, the key to constitutional equality protection is weakness. The use of $s .15$ is an acknowledgement of political defeat. The political convention we call the legislative process cannot be trusted to do the job. As Ely notes, the foundational imperative that justifies a s. 15 type preemption is the distrust of the political process based on a perceived unmoderated community prejudice against certain types of community members, under which those members become powerless. Accordingly, blinding current community prejudice proved through an analysis of historical community conduct is the rock on which the $\mathrm{s}$. 15 edifice is built. ${ }^{84}$

The Jehovah's Witnesses were an obvious candidate for equality protection not because they stood for something that was good or even neutral, but because they stood

Compare Sopinka J.'s reasons for judgment in McKinney v. University of Guelph, supra note 67

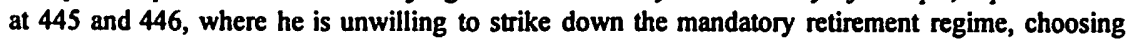
to defer to the "democratic process" rather than exercise the "heavy hand of the law" to his willingness to strike down mandatory retirement in Dickason v. University of Alberta, [1992] 2 S.C.R. 1103 at 1194 , where there is no requirement to defer to the legislature. See the Guido Calabresi commentary associated with supra note 56.

s. Scalia J. makes the point in these inflammatory terms (in dissent, where the U.S. Supreme Court majority prohibits the State of Alabama litigator (acting on behalf of a mother seeking confirmation of patemity and child support) from using its peremptory strikes in a jury selection to exclude males):

In order, it seems to me, not to eliminate any real denial of equal protection, but simply to pay conspicuous obeisance to the equality of the sexes, the Court imperils a practice that has been considered an essential part of fair jury trial since the dawn of the common law. The Constitution of the United States neither requires nor permits this vandalizing of our people's traditions.

J.E.B. v. T.B. as reported in The New York Times (20 April 1994) A14 (National Edition). 
for things that were anathema to the community, and therefore, the courts could be confident that the democratic convention could not properly consider their input. ${ }^{85}$

The reasons for judgment of Wilson J. in $R$. v. Turpin ${ }^{86}$ are the clearest indication that without historical prejudice, a s. 15 claim of discrimination will fail. ${ }^{87}$ At first blush, Sharon Turpin seems a likely candidate for constitutional equality protection. She has been charged with murder. The trial judge has concluded that the statements of her co-accuseds (who are to be tried with her) are "clearly prejudicial to [Ms. Turpin] as they are totally inadmissible against her." Given the peculiar distinction in s. 430 of the Criminal Code, in Alberta Ms. Turpin can elect into the safety of trial by judge alone, elsewhere she cannot. Unfair? Certainly. But it is not constitutionally actionable under s. 15 , because Ms. Turpin's group is only accused murderers. And while this is a group that benefits from the civil liberties associated with the spectre of criminal prosecution, it is not one of those specialized groups that the Supreme Court feels has suffered under historical prejudice. The engine for a constitutional preemption of the political process by way of constitutional equality protection, historical prejudice, is not present.

In my opinion, this aspect of equality protection is one of the key limitations. ${ }^{88}$ It need not, however, impose the chill evident at first blush, and indeed, I would adopt the gloss offered by Laurence Tribe:

The central conceptual problem of the antidiscrimination principle is evident in its terminology. Discrimination is "an act based on prejudice," and its essential elements are therefore an actor and a decision based on invidious rather than rational grounds. When mediated by an antidiscrimination principle, the fourteenth amendment becomes a tool for overturning those injurious legislative acts, judicial decisions, and executive or administrative choices that are motivated by racial or other unacceptable types of bias. The focus under this approach is on the perpetrator of prejudiced action....

A more promising theme in equal protection doctrine may well be an antisubjugation principle, which aims to break down legally created or legally reenforced systems of subordination that treat some people as second-class citizens. The core value of this principle is that all people have equal worth. When the legal order that both shapes and mirrors our society treats some people as outsiders or as though they were worth less than others, those people have been denied the equal protection of the

The defence factum in the 1938 sedition case of Duval v. $R$ included the following: "Satan has become the prince of the earth and humanity is in his grip; all human institutions are in his control; the church, the financial bodies, the political governments, the bar, the bench, have become corrupt and serve the purposes of Satan, who has blinded humanity." Cited in G. Botting, Fundamental Freedoms and Jehovah's Witnesses (Calgary: University of Calgary Press, 1993) at 85.

[1989] 1 S.C.R. 1296. Here Wilson J. expands on the caveat she provided to McIntyre J.'s s. 15 analysis in her reasons for judgment in Andrews, supra note 12 at 154 (located in the portion of her reasons dealing with $s .1$, but in fact, providing a $s$. 15 gloss). See further Linden J.A. (in dissent) in Egan, supra note 51 at para. 129.

See the much more equivocal position of McIntyre J. in Andrews, ibid. Contrast his statements at 168 that seem to require a clear finding of discrimination with those at 174 that appear to endorse the finding of a simple distinction only. See also supra note 25 . 
laws.... The antisubjugation principle is more concerned with the burdens government action imposes on suspect groups than with what prejudices lurk in the hearts and minds of government actors. The goal of the equal protection clause is not to stamp out impure thoughts, but to guarantee a full measure of human dignity for all. The Constitution may be offended not only by individual acts of racial discrimination, but also by government rules, policies or practices that perennially reenforce the subordinate status of any group. Mediated by the antisubjugation principle, the equal protection clause asks whether the particular conditions complained of, examined in their social and historical context, are a manifestation or a legacy of official oppression....

The antisubjugation principle thus does not argue for adopting disparate impact as a per se rule; strict judicial scrutiny would be reserved for those government acts that, given their history, context, source, and effect, seem most likely not only to perpetuate subordination but also to reflect a tradition of hostility toward an historically subjugated group, or a pattern of blindness or indifference to the interests of that group. This "test plainly would require intuitive judgments, but judgments resting on correlations between observable events, without explanations as to cause, are not necessarily unsound." There is a common-sense appeal, for example, in the notion that a government decision to combat traffic congestion by walling a white enclave off from a black neighbourhood, or to zone a white neighbourhood for large lots that exclude the possibility of low-income housing, is more likely to be the product of racial animus or indifference than is a decision to subsidize a shopping mall project. ${ }^{39}$

\section{Using the "Tax Expenditure" Budget}

For over twenty years various tax gurus have promoted the "Tax Expenditure Budget" as a useful tool in analyzing the effect of particular provisions of the Income Tax Act. In the words of Faye Woodman:

The most significant aspect of the tax expenditure concept is its ability to illuminate, for the scrutiny of political reformers and judicial reviewers alike, the types and costs of subsidies provided by the tax.... [T] he tax expenditure approach will help [courts] ... to understand the cost, distribution and economic impact of many tax concessions. 9

The Department of Finance has produced at least three tax expenditure budgets that can provide an informative spin on the purpose and effect of the particular provision under scrutiny. ${ }^{91}$

\section{Weighing Adverse Effect Against Either Administrative Imperative or Conflicting Constitutional Imperative: Developing a Calculus of Discrimination (the Subjugation Quotient?)}

The right to work, the right to welfare, the right to unemployment insurance, the right to education, the right to be licensed (as a lawyer, laundry owner or driver), the right to receive government benefits, the right to be included in or excluded from the 
government's definition of either the taxing or the benefit delivery unit; these are all rights, but not necessarily rights that are created equal.

Similarly the justification for the curtailment of such rights by government operates on a sliding scale. In the easy case, the curtailment is based on the legislature's unconstitutional prejudice. Progressively more difficult, the curtailment may be based on administrative convenience, administrative efficiency, or a conflicting but preempting constitutional imperative.

If we are serious about developing a meaningful equality protection scrutiny of things like our progressive income tax regime, it seems inevitable that the Supreme Court will have to revisit the rationality test last championed unreservedly by McLachlin J. for the British Columbia Court of Appeal in Andrews itself.92

While a rationality (or relevancy) test need not occupy centre stage, surely it is a factor in the contextual mix that contributes meaningfully to the evolution of the "best" answer. McIntyre $\mathrm{J}$. in Andrews, on behalf of the Court, clearly rejects an all-purpose rationality test on the grounds that it is too acquiescent to government. The rejection is not, however, in absolute terms. Indeed, as McLachlin J. has noted in Miron, McIntyre $\mathrm{J}$. is plumbing for a middle ground somewhere between McLachlin $\mathrm{J}$. and Professor Hogg. ${ }^{93}$ Without repudiating the rejection of rationality as "The Basic Test," the late Tarnopolsky J.A.'s reaction to Andrews in Children's Aid Society provides some useful commentary that may assist a court eager to resuscitate rationality, not as a basic test, but as part of the contextual soup. ${ }^{94}$

Indeed, at least five members of the Supreme Court now seem ready to revisit the implementation of some kind of relevancy test at the s. 15 level:

A more comprehensive contextual approach must be taken to determine the relevancy of the personal characteristic in question to the functional values underlying the law."

[T] he nature, quantum and context of an economic prejudice or denial of such a benefit are important factors in determining whether the distinction from which the differing economic consequences flow is one which is discriminatory. If all other things are equal, the more severe and localized the economic

Re Andrews and Law Society, B.C. (1986), 27 D.L.R. (4th) 600.

See supra note 25 .

Like Laskin, C.J., Tarnopolsky J.A. was an old civil liberties hand who was not given the opportunity to make anything other than preliminary judicial comments on the Charter. As with Laskin (see supra note 38), Tarnopolsky J.A. in Re Catholic CAS of Metro Toronto v. S.(T.) (1989), 69 O.R. (2d) 189 (C.A.) seems particularly perplexed with Charter interpretations that ignore or misunderstand the rich academic heritage of the issues. To the author of Discrimination and the Law, the Supreme Court's brave new world in Andrews does not seem to get much more than a passing grade. In particular, the Supreme Court's emphasis on pillorying separate but equal and the apparent rejection of any rationality test at the $s$. 15 level curries no enthusiasm from Tarnopolsky J.A.

Egan v. Canada, supra note 2 at 624, LaForest J. (Lamer C.J.C., Gonthier and Major JJ. concurring). See supra note 26. See generally Gonthier J. in Miron v. Trudel, supra note 2. 
consequences on the affected group, the more likely that the distinction responsible for these consequences is discriminatory within the meaning of $s .15$ of the Charter.

Although a search for economic prejudice may be a convenient means to begin a s. 15 inquiry, a conscientious inquiry must not stop here. The discriminatory calibre of a particular distinction cannot be fully appreciated without also evaluating the constitutional and societal significance of the interest(s) adversely affected. Other important considerations involve determining whether the distinction somehow restricts access to a fundamental social institution, or affects a basic aspect of full membership in Canadian society (e.g. voting, mobility). Finally, does the distinction constitute a complete non-recognition of a particular group? It stands to reason that a group's interests will be more adversely affected in cases involving complete exclusion or non-recognition than in cases where the legislative distinction does recognize or accommodate the group, but does so in a manner that is simply more restrictive than some would like.\%

\section{Ignorance as a Possible Foundation for Decision Making}

The dissent of Harlan J. in Plessy v. Ferguson ${ }^{97}$ (the separate but equal railway carriage case out of Louisiana) is eloquent and seminal partly because of Harlan J.'s "pride of race. ${ }^{198}$ Notwithstanding the judge's mainstream acceptance that whites were superior, this pigeon ${ }^{99}$ understood that government action that reinforced that article of Spencerian faith was off-side. This is a judge who is saying to himself: "I am probably right, but I am not going to allow the offices of my government to prove my case. That is a vision of government we have rejected. We need Democracy plus. And the plus deals with protecting the individual over time so that his or her voice for change over time will be heard." 100

The United Church's ruminations on gay leadership are also instructive.

To begin with, the challenge is significant. The private religious community that controls its secular leadership from below does not have the opportunity to impose equality protection solutions from above. Unlike a Court of Appeal pronouncement on s. 15, or a papal encyclical, any equality protection solution must be of the membership and accepted by the membership. No pigeon solution here.

Egan v. Canada, supra note 2 at 640, L'Heureux-Dubé J. To me, this is clearly Tribe's Model VII territory. The anglophone liberals on the Court (McLachlin, Cory and Iacobucci JJ.) would leave this exercise to s. 1. While Sopinka J. resolves Egan in favour of the government under s. 1, he does so by citing the revisionist Hogg, perhaps suggesting that he may be susceptible to moving the analysis back into s. 15 for the reasons given by Professor Hogg (see supra note 25). 163 U.S. 537 (1896). The majority judgment of Brown J. (who remembers him) is also interesting because it makes the democrat's point pretty well, and in hindsight, provides a useful cautionary against putting all our equality protection eggs in one democratic basket. Plessy v. Ferguson, ibid. at 554.

See supra note 52.

100 Beware, this is revisionist territory, unsupported by the text of Harlan J.'s reasons. There are Canadian echoes of this as well. In the Alberta Press case (supra note 38), Duff C.J. relies on the Preamble to the Constitution Act, 1867 and its references to Parliament to conclude that there is a constitutional identification of the utility of free and open public discussion. See also the comments of Justice Holmes in dissent in Lochner (supra note 62). 
Also, the answer is not merely academic but goes to important community values. For a large segment of this particular church's community (like the accommodation of the Jehovah's Witnesses in Quebec) an accommodation of gays and lesbians is an embrace of untouchables.

Faced with these challenges, the church provides an effective and meaningful response to the problem, based on ignorance. As the church council's resolution notes, ${ }^{101}$ we do not fully understand God's intentions in providing human sexuality. Beyond the obvious advantage of procreation, the carnal aspect of our being has facets that continue to trouble each and every one of us. In these circumstances, until the wonder of God's will and creation is made more manifest to us, so the church leadership reasons, we cannot exclude from positions of leadership a segment of our community based on such fragmentary understanding.

Harlan J. rejected separate but equal, if not out of ignorance then at least as a result of democratic modesty. The United Church of Canada admits gays and lesbians to positions of leadership, out of ignorance. That is as it should be.

This is not the Nixonian counsel of mediocrity. G. Harrold Carswell stay put. Rather here we are back to Aristotle: Proteus is changing in ways we do not understand and the equality protection methodology must invite reasoning that expressly accommodates decision-making based on ignorance. A contextual approach facilitates this.

\section{Evidence, Evidence, Evidence}

There are two ways of winning at litigation: you can do it either with the law or with the evidence. Faced with Lochner, counsel for the State of Oregon opted to concentrate on the evidence. The Brandeis brief was born. ${ }^{102}$

Whichever way the court tilts in terms of enhanced or reduced equality protection scrutiny of the Income Tax Act, the loser should take some comfort from the Brandeis gambit. In a contextual world there are no absolute losers. Changes in circumstance or refinements of the evidentiary ordnance hold out a prospect for future success notwithstanding present defeat.

"We confess before God that as a Christian community, we have participated in a history of injustice and persecution against gay and lesbian persons in violation of the Gospel of Jesus Christ. ... We acknowledge that we are unclear at the present time, as to what God's complete intention is in relation to human sexuality, even as we affirm our support and appreciation for the gifts of Christian marriage, the charism of celibacy, and the way of chaste singleness. ... Council Declared ... That all persons, regardless of their sexual orientation, who profess Jesus Christ and obedience to Him, are welcome to be or become full members of the Church. All members of the Church are eligible to be considered for ordered ministry." "Membership, Ministry and Human Sexuality," Statement of the 32nd General Council, United Church of Canada, 1990.

See Muller v. Oregon, 208 U.S. 412 (1908) at 419, 1n. for an abstract of the brief "submitted" by Mr. Louis D. Brandeis on behalf of the State. See Tribe, supra note 16 at 569, who notes that notwithstanding Lochner, the Brandeis brief helped save a number of statutes from invalidation. 
Given the government's extraordinary advantages in any evidentiary battle over both the legislature's purpose and intent as well as the legislation's effect (what solitary litigant could be a match for a government's Charter Secretariat that is committed to producing the evidence of self justification?), our courts may wish to err on the side of the equality protection complainant, taking comfort from the realization that the government is best positioned to deliver the contextual explanation.

\section{Rules of Thumb: Helpful Short-cuts}

A contextual approach accommodates the introduction and evolution of short-cut tests that provide a simple analytical framework that is readily understood and that seems to produce sensible answers.

For example, irrebuttable government presumptions based on group characteristics offend the core value that individuals are distinctive. Some fifteen year-olds are better drivers than their seventeen year-old brothers. Some sixty-six year-olds have a greater need and capacity to work than their sixty-four year-old colleagues. Arbitrary rules based on age that provide no opportunity for the individual who is on the wrong side of the distinction to rebut the presumption that animates the policy strike us as unfair and perhaps suspect.

On the other hand, the administrative imperative for such rules is often self-evident (and sometimes not so self-evident ${ }^{103}$ ). A middle ground rule that looks with suspicion upon irrebutable presumptions, while retaining a willingness to accept such distinctions based on a broad range of administrative justifications, provides a utilitarian and flexible solution to a potentially troublesome issue. ${ }^{104}$

\section{Contextual Peroration}

The preceding does not presume to be an exhaustive catalogue of contextual factors. It is only a sampler that hopefully triggers interest in the capabilities of a contextual methodology. Before returning to the question raised in the introduction, a final word on Charter process seems warranted.

\section{CONFIRMING THE OBVIOUS: FOR THE DIFFICULT CASE, THE CONTEXTUAL ANALYSIS HAS TO BE DONE IN SECTION 15, NOT SECTION 1}

Charter litigators talk about $\mathbf{s}$. 1 evidence. In equality protection litigation, this is a dangerous misnomer. Given the nature of the equality and discrimination concepts, the delivery of the so-called $s$. 1 evidence is required up front so that the court can meaningfully grapple with the contextual tests necessary to crack the s. 15 puzzle. 
Notwithstanding the generic Charter architecture that saves the issue of governmental justification for s. 1, given the protean nature of equality protection, the generic must give way to the more specific requirements of s. $15 .{ }^{105}$

\section{E. TESTING THE MISSION STATEMENT: APPLYING THE CONTEXTUAL METHODOLOGY TO THE PROBLEMS RAISED IN THE INTRODUCTION}

Does any of this provide assistance with the problems set out in the introduction? I think so. Here is the introductory question again with thumb sketch responses based on the contextual factors discussed:

Does our government unconstitutionally discriminate against:

1) natural parents, by providing additional U.I. benefits to adopting parents;

The decision of the Federal Court of Appeal in Schachter ${ }^{106}$ is wrong. Canadian infertility has not reached such epidemic proportions that natural parents (as opposed to adopting parents) now constitute a subjugated minority requiring constitutional equality protection. ${ }^{107}$

2) eighteen year old workers, by restricting the GST Credit to those nineteen and over;

Age is an enumerated ground. While it may be an uphill battle to prove historical prejudice that amounts to subjugation against working youths, such a conclusion is not inconceivable. The irrebutable presumption of dependency based on age is troubling and tests should be established to keep the governmental rite-of-passage line drawers honest and constitutionally accountable. $^{108}$

3) custodial single parents, by moving the incidence of taxation on the income used to fund maintenance payments from the payor to the payee;

Again, proving historical prejudice that approaches subjugation against custodial single parents seems difficult, but not inconceivable. Any Tax Expenditure Budget analysis that confirms a commitment by government to use the impugned program to deliver significant benefits to the putatively subjugated group is effective and meaningful evidence that the program has

See e.g. Gonthier J. in Thibaudeau, supra note 2 at $488 \mathrm{ff}$ (note that Gonthier J. is the author of the Bon-Secours rules - see supra note 40). See also the Hogg references in supra note 25. [1990] 2 F.C. 129.

See supra, Part III.C.4. The issue before the Supreme Court of Canada was restricted to a determination of the appropriate remedy. Both Lamer C.J. and LaForest J. show significant frustration with their inability to consider the foundational issue of whether or not there was a constitutional transgression.

See supra, Part III.C.9. 
neither the intention nor the effect of perpetuating unconstitutional discrimination. ${ }^{109}$

4) smokers and drinkers, by taxing their recreational consumables at a higher rate;

While smokers are a group that is rapidly acquiring the badges of the subjugated, we may not be there quite yet. In any event, the Subjugation Quotient (S.Q.) seems pretty low: weighing the rights abrogated against administrative factors such as the necessity of raising money and the additional health care costs associated with these consumables does not seem to provide an imperative for judicial action. This is rationality territory; John Stuart Mill's equality protection analysis of such taxes seems reasonable. ${ }^{110}$

5) gays and lesbians, by: a) excluding them from the ambit of our human rights legislation; and b) excluding them from obtaining the status of spouse under the Income Tax Act;

a) The S.Q. of gays and lesbians in Canada seems particularly high and their subjugation, I assume, is readily provable. Accordingly, full bore equality protection seems called for, and half measures like separate but equal are particularly objectionable. Our legislators cannot pick and choose among the untouchables in extending human rights; the courts must add this group to such legislation."

b) If the Tax Expenditure Budget analysis confirms that spousal status in the Income Tax Act is a relatively neutral status (advantageous in terms of family credits but disadvantageous in terms of the attribution rules and the definition of non-arm's-length); if there is no proof that the definition of spouse either was intended to perpetuate or has the effect of significantly perpetuating the subjugation and if the government can demonstrate normative tax structure concerns that justify retaining the current definition of spouse; the spousal status status quo may be supportable. 112

6) aliens, by prohibiting lawyers from practicing their trade until they become Canadian citizens;

Resident aliens are a historically subjugated group. The right to work is important. The legislation's evident objectives seem particularly trivial. Section 15 equality protection here is appropriate. If the right were less important or the legislative objective more substantial, the right answer might be different. Lawyers are not my favourite candidates for equality protection. ${ }^{113}$

See supra, Part III.C.2, 3 and S.

See Mill, supra note 18 at 90 .

See supra, Part III.C.4, 6 and 7.

See supra, Part III.C.2, 3, 4, 5 and 6.

See supra, Part III.C.6. 
7) women, by restricting child care expense deductions in the Income Tax Act.

This is another enumerated group. The S.Q. seems significant, but not off the meter as with gays and lesbians, and it seems to be decreasing. Members of the group have assumed positions of real authority in most of the community's power centres. Accordingly, there is a significant reluctance to pre-empt the political convention process. The absence of a deduction for these expenses seems to be a real barrier to female access to a male-dominated work world and may well reflect conscious historical efforts at subjugation. On the other hand, if the Haig-Simons definition of income has merit (income equals consumption plus savings), an income tax system that fails to tax the consumption value of stay at home women seems to undertax women significantly (or at least traditional two spouse families where one spouse works less than fulltime). ${ }^{114}$ I would like to hear and read more evidence on the history of the subjugation of women, the role of the Income Tax Act in that process (both as to legislative intentions and unintended effect) and the effect of any changes to this particular provision in terms of Justice Estey's first and second "state interests": a properly functioning normative tax structure and equity among taxpayers. Justice lacobucci is right, we need more evidence, but not the kind he wants. ${ }^{115}$

\section{CONCLUSION}

In the heat of the rhetorical charge, those of us who are committed to gay rights, gender equality and the freedom to smoke without undue harassment may tend to wrap our political imperatives in equality garb that begs no dissent. For the proselytizer in us, the argument is irresistible. For the political realist in us, the argument is too bold.

Instead, a contextual methodology is needed if we are to use s. 15 of the Charter as a meaningful dedoubt contributing to the attainment of the broad assortment of community values we hold dear. Not only does this approach conform to the architecture of s. 15, more important, it provides the necessary flexibility to meet the Aristotlean challenge which, in today's political vernacular, is restated as: "Not the right answer, stupid. The best answer."

The final word is reserved for the Supreme Court's leading contextualist:

It must be emphasized that there are no absolute preconditions to, or preclusions from, a finding of discrimination. Although the presence of one or more of the aforementioned factors in either of these two categories may tend toward the conclusion that the impugned distinction is discriminatory, it does Income Tax" (1977) 90 Harv. L. Rev. 1573. For the contemporary spin in which the benefit (pedestal) is seen as a sinister inhibition of full participation in the glories of the workplace, see E.J. McCaffery, "Taxation and the Family: A Fresh Look at Behavioral Gender Biases in the Code" (1993) 40 U.C.L.A. L. Rev. 983 at 1001. 
not inevitably lead that way. Conversely, the absence of one or more of these factors does not necessarily preclude there still being a finding of discrimination. Courts must treat these considerations as a matrix rather than as a single equation, and as the microscope rather than as the object being studied.

Equality and discrimination are notions that are as varied in form as they are complex in substance. Attempts to evaluate them according to legal formulas which incorporate rigid inclusionary and exclusionary criteria are doomed to become increasingly complex and convoluted over time as "hard" cases become the rule rather than the exception. I prefer to steer clear of those rocky shoals, if at all possible, and to adopt a pragmatic and functional approach to $\mathrm{s}$. 15.1 believe that an analysis that examines both sets of factors in the basic framework set out above will enable courts to arrive in a principled manner at an answer that reflects as closely as possible the experience of those in the affected group. If, after examining the nature of both the group and the interest affected, a court concludes that the impact of the impugned distinction is capable of inflicting a non-trivial discriminatory "scar" on the affected group, then it must conclude that this distinction is discriminatory. 16 